\title{
Invited Lectures
}

\section{Invited lectures}

\section{Session 1 Pesticides Discovery}

Yong (Central China Normal University, China) らは, 農薬 化合物之受容体との相互作用において，化合物の活性なコ ンフォメーションに基づいて農薬を合理的にデザインする ことを検討し，その最近の成果として以下の 3 つのケース について報告した。ケース 1. DFT (density functional theory）は，分子の立体構造や電子状態，反応性およびスペク トル的性質を理解する上で強力なツールであり，これを QSAR に応用することで，ターゲットに関する情報がなく とも活性なコンフォメーションを予測できる。一連の PPO 阻害型除草剂について DFT ベースモデルでの検討を行い, その有用性を示した。 ケース 2. ALS 阻害型除草剂の抵抗 性問題に関し，分子のコンフォメーションのフレキシビリ ティーと抵抗性との相関を見出した．特にコンフォメーショ ンのフレキシビリティが架橋原子に影響を受けること，す なわちスルホニルウレアやスルホンアミドより酸素原子が フレキシビリティがあることから，2-aroxyl-1,2,4-triazolo[1,5c]pyrimidine 類をデザインし合成した. その結果 2 つの化合 物が野生株と変異株に対し同等の阻害活性を示したことか ら，抵抗性種に有効な除草剂リードとしての可能性が示唆 された。ケース 3. 薬剤とレセプターとの相互作用は，薬 剂の活性なコンフォメーションとレセプターの結合ポケッ トの中の残基との相互作用である。一般的には，レセプ ターの結合ポケットの残基は部分的にはフレキシブルであ るが，他の部分はリジッドである．相互作用を最大化する ために，そのフレキシブルな残基との相互作用を最適化す ることが薬剤の効果改善に効率的であるとの考えで， ス卜 ロビルリン系殺菌剤のデザインを検討し，薬剤とレセプター との相互作用を改善する方法として，コンフォメーション 的にフレキシブルなレセプター残基とリガンドとの相互作 用を最大化することの有用性を示した。（\#4）

Zhong Li (East China University of Science and Technology) らは，ニトロメチレン基が cis のネオニコチノイド系化合物 に関して，化合物のデザイン，多様な構造の化合物の合成 をおこない，殺虫活性を評価した．イミダクロプリドはニ トロ基が trans であるが，これを cis に固定することで抵抗 性系統に対しても有効なリードを見出すべく，ニトロメチ レン基を有する化合物のエナミンの反応性を利用してさま ざまな化合物をデザイン，合成した．クロトンアルデヒド との反応で得られた新たに 6 員環を形成した誘導体のトビ イロウンカに対する活性は，感受性系統に対するイミダク
ロプリドの活性にはかなり劣るが，感受性系統と抵抗性系 統との活性差はほとんど見られなかった。ジアルデヒドと の反応では，そのメチレン鎖長により反応生成物が異なり， グリオキサール，マロンアルデヒドでは 2 量体を与えた（殺 虫活性は低下)。一方，スクシンアルデヒドとの反応では， 3 環性誘導体（1）を与え, ツマグロヨコバイの抵抗性系統 に対して高い効果を示し, 光安定性も改善された。但し, 感受性系統に対するイミダクロプリドの活性には及ばなかっ た. (\#5)

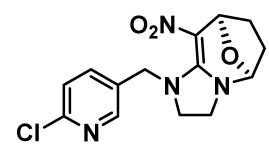

1

津幡（日本農薬（株））は，植物抵抗性誘導型病害防除 剂に関してレビューするとともに，これまでに開発または 公表されてきた化合物を化学構造面から考察し，ある種の (ヘテロ）芳香族カルボン酸が植物の抵抗性を誘導するとの 仮説を示した。当初はチバガイギー社の特許から 1,2,3-チア ジアゾール誘導体に抵抗性誘導活性があるとの仮説に基づ き探索を行ったが，1,2,3-チアジアゾール-5-カルボン酸エス テルおよび関連誘導体が高いイネいもち病防除活性を示し たことから，上記の仮説に至った。 1,2,3-チアジアゾール-5カルボン酸誘導体に関して抵抗性誘導型イネいもち病防除 剂としての探索を行い, tiadinil（チアジニル）を見出した. チアジニルは，抵抗性誘導剂に特徵的な反応・現象を示し た。イネいもち病防除剤として長期残効性を示す一方，速 効性を要求される場面にも有効であり，育苗箱処理剂なら びに本田処理剂として開発された。水稲における他の病害 ならびに他の作物病害にも有効であることを示した。（\#6）

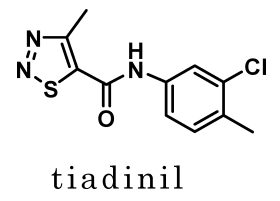

佐々木（神戸大学）らは, 合成ストリゴラクトン誘導体 の植物発芽刺激活性について，構造活性相関を中心に報告 した. ストリゴラクトン（Strigolactones）は，半寄生植物 の発芽を誘導する天然物として 1966 年に発見され，数多く の類縁物質が植物から単離・構造決定された. 最近の研究 で，これらの化合物は，植物の分枝を抑制する機能を示す 
ことが明らかとなった。佐々木らは，合成ストリゴラクト ン誘導体 GR 24 の Michael acceptor 構造と生物活性発現の 関連を追究するために，新規イミノ化合物 GRN 24 および その誘導体を設計・合成し（Fig. 1), 構造活性相関解析研 究を進めた結果, Michael acceptor 構造が必須要件ではなく, 新規イミノ系化合物も強い発芽刺激活性を示すことが明ら かとなった。 また, 幾つか新しい発芽刺激活性物質の合成 研究も紹介された.（\#7）

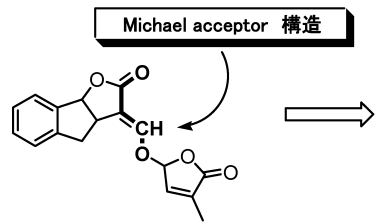

GR 24

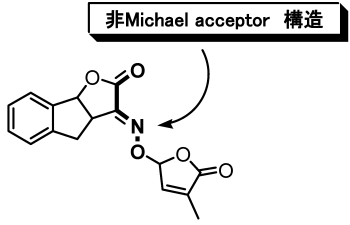

GR 24 imino-analogue(GRN 24)
Fig. 1 Structures of GR24 and GRN24

Kim（Dongbu HiTek Co., Ltd., Korea）らは，新規除草剂で ある metamifop（日本名：メタミホップ）の生物活性と作用 機構について報告した。 メタミホップは土壤処理と茥葉処 理の両方で有効な除草剂である.イネ科の雑草を選択的に 防除するが，毒性がほとんどないことから，安全性，使用 範囲などが既存の薬剂に比べ優れているという。メタミホッ プの作用機構解析の結果，その作用部位は ACCase である ことが明らかとなり, ACCase の非拮抗阻害剂であることが 明らかとなった。また，メタミホップの選択性をイネとイ ヌビエの ACCase を用いて検討の結果, メタミホップは高
い選択性を示すことが明らかとなった。現在，メ夕ミホッ プは 16 カ国で販売され, グローバルな農薬登録を進めてい る. (\#8)

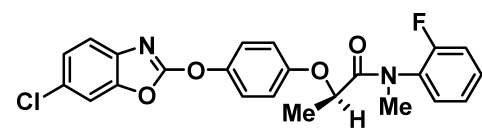

metamifop

Koo（Moghu Reasearch Center, Korea）らは，新規除草剂 MRC-01 の生物活性と作用機構解析について報告した。 MRC-01 はイネ科雑草に強い殺草活性を示すが，低毒性で あり, 安全性も紹介された。 また, Koo らはトウモロコシ の根部生長阻害活性を指標とするバイオアッセイ系で MRC01 の作用機構を検討した。 セルロース生合成阻害剂である dichlobenil および quinclorac の活性と比較したところ, MRC-01 は明瞭なセルロース生合成阻害活性を示したが, 作 用様式は dichlobenil および quinclorac と異なることが示唆 された。その作用部位は現在検討中であるという。MRC-01 の現地試験は日本，韓国，アメリカで現在展開している. (\#9)

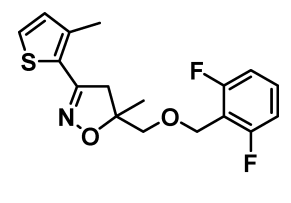

MRC- 01

王 敬銘（秋田県立大学), 津幡健治（日本農薬（株） 総合研究所) 